\title{
Contribution of the Bindura Community Share Ownership Trust to Rural Development in Bindura Rural District Council of Zimbabwe
}

\author{
Jeffrey Kurebwa, PhD (Corresponding author) \\ Department of Peace and Governance, Bindura University of Science Education, \\ P. Bag 1020, Bindura, Zimbabwe \\ Email: jeffkurebwa@yahoo.co.uk Mobile Number: +263772121563
}

\section{Emmaculate Ngwerume}

Department of Peace and Governance, Bindura University of Science Education, Zimbabwe

\begin{abstract}
Charles Massimo
Department of Peace and Governance, Bindura University of Science Education, Zimbabwe
\end{abstract}

Accepted: November 16, 2014

Doi:10.5296/ jpag.v4i4.6624 URL: http://dx.doi.org/10.5296/ jpag.v4i4.6624

\begin{abstract}
This research analysed the contribution of the Bindura Community Share Ownership Trust (BCSOT) to Bindura Rural District Council (BRDC) in Mashonaland Central Province of Zimbabwe. Key informant interviews and the survey questionnaire were used for primary data collection while secondary sources such as the Indigenisation and Economic Empowerment Act of 2007 and Statutory Instrument of 2010 which established the Community Share Ownership Trusts were analysed. The research found that 45 projects had been embarked on by the BCSOT. These projects included water, health, education and roads. It concludes that these projects had greatly contributed to rural development in Bindura Rural District Council. The respondents indicated that if CSOTs are to succeed, there should local community involvement in the identification of projects. The research recommended that the BCSOT should also establish small to medium enterprises and other income-generating projects in order to improve rural livelihoods.
\end{abstract}

Keywords: Rural development, indigenisation, community share ownership trusts. 


\section{Introduction}

Rural communities in Zimbabwe have suffered decades of poverty and underdevelopment. They are still relatively less developed than urban areas. The research looks at the contribution of the Bindura Community Share Ownership Trust (BCSOT) to rural development. Despite the abundant natural resources in Zimbabwe, rural communities living close to mines have not benefitted. The efforts by the Government of Zimbabwe to improve rural development in the country since 1980 have been significant in terms of its commitment and participation in the development process. Despite the considerable capital injection, human and material resources committed to rural development projects, there has been no corresponding improvement in the performance of community projects beneficial to individual households such as health care centers, roads, cattle dips and water supplies in most districts of the country (Rono and Aboud, 2003).

There has been a growing awareness of the importance of collective natural resource management practices and institutions, and recognition of the ways that historic forces have disrupted local people's ability to manage the lands and resources they depend upon. A wide range of policy makers and development and conservation practitioners have supported efforts to revive or bolster local natural resource management institutions in response to various economic, social, environmental and political pressures. Increasingly, debates over local communities' ability to manage their lands and natural resources are part and parcel of broader struggles over political and economic power and authority in African countries. Unfortunately, extractive industries, especially those involved in gold and diamond mining have neglected local communities in pursuit of profits (Sustainable Development Solutions Network, 2013).

\section{The Concept of Rural Development}

Rural development is the far - reaching transformation of the social and economic structures, institutions, relationships and processes in any rural area (Bealer; Willits and Kuvlesky, 1965). It also refers to agricultural and economic growth and balanced social and economic development, with emphasis on the equitable distribution as well as the creation of benefits (Bealer, 1965). Some of the goals of rural development include equitable access to arable land, distribution of income, widespread empowerment in health, nutrition and housing, and greatly broadened opportunities for all individuals to realize their full potentials through education and strong voice for all rural people in shaping the decisions and actions that affect their lives (Coombs and Ahmed, 1974). There is no single paradigm suitable for sustainable rural development. Every country must look inward to design appropriate strategies in order to empower its citizens (Ladele, 2005).

Rural development may also be defined as overall development of rural areas to improve the quality of life of rural people. It is an integrated process, which includes social, economical, political and spiritual development of the poorer sections of the society (Chambers, 1983). Rural development can be further defined as helping rural people set the priorities in their own communities through effective and democratic bodies, by providing the local capacity; investment in basic infrastructure and social services, justice, equity and security, dealing 
with the injustices of the past and ensuring safety and security of the rural population.

According to Chambers (1982) rural development is a strategy to enable a specific group of people, poor rural women and men, to gain for themselves, and their children more of what they want and need. It involves helping the poorest among those who seek a livelihood in the rural areas to demand and control more of the benefits of rural development. The group includes small scale farmers, tenants and the landless. Thus, the term rural development may be used to imply any one of the above-mentioned connotations.

Indigenisation is the practice of transferring privately owned economic entities into public ownership. It carries the notion of creating an opportunity for the poor communities to work out of poverty. Indigenisation responds to the notion that previously marginalised social groups like rural communities must be empowered to develop their areas. The poverty in the rural areas is a result of factors that lie outside of the residents thereof. It is a result of the superstructure that puts in place socio-economic bottlenecks that prohibit the rural communities from ascending out of poverty and underdevelopment (Matunhu, 2012).

\section{Local Economic Development (LED) Principles}

Local and community development initiatives in Zimbabwe have been premised on the traditional framework of development that emphasizes handouts, relief and other forms of external aid for spearheading development agendas and enhancing livelihoods (Zikhali, Ncube and Tshuma, 2013). Local communities still engage in small income generating projects aimed at improving livelihoods for a few households, instead of engaging in community wide interventions that are aimed at fostering economic growth and competitiveness of the whole locality. This is because Zimbabwe has not made efforts on recommendations from researches being done globally that advocate the adoption of LED as a remedy to poverty and economic challenges facing localities. Helmsing (2010: 2) defines LED as 'an integrative approach in which public, private and civic actors define and manage resources to create and maintain place prosperity in a well defined area'. Against this backdrop, it is clear that indigenous knowledge and endogenous resources in Zimbabwe are not being collectively exploited to address the general economic ills in the localities but rather fragmented individual efforts for self betterment is pursued (Zikhali, Ncube and Tshuma, 2014).

The basic principles underlying LED are;

(i) Poverty and unemployment are the main challenges facing developing countries. LED strategies must therefore, prioritize job creation and poverty alleviation,

(ii) It must target previously disadvantaged people, marginalized communities and geographical regions, to allow them to participate fully in the economic life of the country,

(iii) It must promote local ownership, community involvement, local leadership and joint decision making, 
(iv) The use of local resources and maximizing opportunities for development,

(v) It involves the integration of diverse economic initiatives in an all-inclusive approach to local development,

(vi) It is participatory in approach. It involves the inclusion of different stakeholders so that their views, concerns and issues can be included in the planning process (Development Planning Unit, 2001).

\section{Why Indigenisation in Zimbabwe}

According to the Indigenisation and Economic Empowerment Act (Chapter 14:33) of 2007, indigenisation 'is a deliberate involvement of indigenous Zimbabweans in the economic activities of the country, to which hitherto they had no access, so as to ensure the equitable ownership of the nation's resources' while indigenous Zimbabwean means any person who, before the 18th April, 1980, was disadvantaged by unfair discrimination on the grounds of his or her race, and any descendant of such person, and includes any company, association, syndicate or partnership of which indigenous Zimbabweans form the majority of the members or hold the controlling interest'.

On Economic Empowerment, the Act defines it 'as the creation of an environment which enhances the performance of the economic activities of indigenous Zimbabweans into which they would have been introduced or involved through indigenisation'. An analysis of these definitions clearly shows that, the indigenisation and economic empowerment programme is one designed to empower black Zimbabweans that were disadvantaged prior to the country's independence in April 1980. According to the National Indigenisation and Economic Empowerment Board (NIEEB) the programme is indeed noble, as it gives, in principle, Zimbabweans from all walks of life the opportunity to participate meaningfully in the country's economic activities. It enables socio-economic transformation for the benefit of Zimbabweans (Mabhena and Moyo, 2014).

The Indigenisation policy in Zimbabwe is both political and economic. It is political in that it aims to correct the colonial injustices, and it is economic in that it seeks to empower the marginalised communities to develop themselves (Dube, 2013). Indigenisation does not apply to state-owned economic entities because these are already benefiting the public. For an economic entity or asset to be viewed as indigenised, the property right must have belonged to the private sector. In the case of Zimbabwe, the communities and employees are given 20 percentage points of the $51 \%$ controlling stake and the government, through the Sovereign Wealth Fund [SWF] or National Indigenisation and Economic Empowerment Fund [NIEEF], manages the remaining 31 percentage points.

Gaomab (2010) notes that the origin, imperative and the need of having indigenisation policies within Africa, particularly, Southern Africa is based on the reality that an economy can flourish if it can meet the needs of its citizens and their enterprises in a sustainable and developmental manner. As such, indigenisation can only play a vital role in human and 
economic development only if the political and economic system of a nation is build on the full potential of all persons and communities across the length and breadth of a country, regardless of political affiliation. The essence of indigenisation lies in spreading the benefits of economic growth to the majority, making economic growth premised on inclusion sustainable. In this way, indigenisation programmes are concerned about benefits of economic transformation and empowering the previously disadvantaged people by means of interventions rooted in addressing ownership and control skewdness.

The indigenisation drive in Zimbabwe resonates with the ideas of Coetze (2010) who indicate the common reasons for indigenisation as:

(i) Delivery of critical infrastructure such as the construction of roads, dams, or public buildings,

(ii) Social and economic equality,

(iii) Resentment of foreign control of major industries,

(iv) Prevention of exploitation and large-scale labour layoffs,

(v) Control of monopolies,

(vi) To keep the means of generating wealth in public control,

(vii) To reduce the power of private capitalists, and

(viii)To allow the profits of business to be shared by the state.

Article 21(1) as read with Article 22(1) of The African Charter on Human and People's Rights provides that 'freely All peoples shall dispose of their wealth and natural resources. This right shall be exercised in the exclusive interests of the people. In no case shall a people be deprived of it'. Indigenous Zimbabweans deserve the same and should freely dispose of their wealth and natural resources. Article 2 of the International Covenant on Economic, Social and Cultural Rights also indicates that all citizens within a country must benefit from a state using its natural resources to guarantee socio-economic rights.

Section 14 of Chapter 4 of the Constitution of Zimbabwe provides 'The State and all institutions and agencies of government at every level must endeavour to facilitate and take measures to empower, through appropriate, transparent, fair and just affirmative action, all marginalized persons, groups and communities in Zimbabwe'. Section 20(1)(c) of the same Constitution provides 'The State and all institutions and agencies of government at every level must take reasonable measures including affirmative action programmes to ensure that the youth, i.e. between the ages of 15 and 35 years, are afforded opportunities for employment and other avenues to economic empowerment' (Constitution of Zimbabwe, 2013).

The Constitution of Zimbabwe therefore provides for socio-economic rights that were missing in the old Lancaster House Constitution (1979). For instance it provides specifically 
for the right to education, healthcare, shelter, among others, using the country's available natural resources. Section 3 of Chapter (14:33) of the Indigenisation and Economic Empowerment Act mandates Zimbabwe to take legislative measures to indigenize its economy and to provide support for the economic empowerment of indigenous Zimbabweans and sets the $51 \%$ indigenous quota as minimum.

\subsection{Why Indigenisation of the Mining Sector in Zimbabwe}

On the $25^{\text {th }}$ of March 2011, Government of Zimbabwe published General Notice 114 of 2011 which prescribed the minimum requirements for indigenization implementation plans to be submitted by businesses in the mining sector. The General Notice was issued in terms of the Indigenisation and Economic Empowerment (General) Regulations SI 21 of 2010. The notice set the minimum threshold for which indigenization implementation plans are required in the mining sector. In section 2 of the General Notice, every mining business in which $51 \%$ of shares or controlling interest is not held by indigenous Zimbabweans and whose net value is of or above $\$ 1$ (one United States dollars) is required to submit an indigenization implementation plan within 45 days of the date of publication of the notice. The date for submission of such plans was the $10^{\text {th }}$ of May 2011. In section 3 the notice also sets the timeframe for achievement of minimum indigenization and empowerment quota in the mining sector. It is provided that every non-indigenous mining business shall achieve the minimum indigenization and empowerment quota by the disposal to designated entities within a period of six months from the date of publication of the notice. However, the implementation plan should be approved by the Minister first. The date for mining companies to dispose of the shares was the $24^{\text {th }}$ of September 2011.

The Ministry rejects any indigenisation plan establishing a CSOT without its approval. Acceptance of indigenisation plans depend largely upon ministerial approval of who is to benefit. The Regulations gives the Minister of Indigenisation and Economic Empowerment a largely unfettered discretion to decide whether to approve or reject an indigenisation plan or to attach conditions to such a plan. This arrangement leaves the possibility of plans being accepted and rejected on the basis of 'who' rather than 'what' is proposed in the indigenisation plan (Matyszak, 2011). Rejection may be based upon the extent to which the terms of indigenisation are beneficial to the person identified as a partner rather than whether they meet the criteria set out in the Act or Regulation. By placing the procedure in the hands of the Minister rather than the Board, and by giving the Minister such a broad discretion, the legislation thus appears purposely designed to allow the Minister the possibility of compelling, against the threat of rejection of an indigenisation plan, the inclusion of selected individuals identified by the Minister in indigenisation plans, and the inclusion of such persons only on terms which the Minister deems sufficiently beneficial (Matyszak, 2011).

\subsection{Establishment of Community Share Ownership Trusts (CSOTs)}

To make the communities benefit from the country's natural resources, ten percent $(10 \%)$ of the equity or shareholding of the company or companies exploiting the natural resources in their areas (now technically called the qualifying company or companies) goes directly to the communities. This $10 \%$ which forms part of the $51 \%$ indigenization and economic 
empowerment quota of a qualifying company is held on behalf of the communities by the Community Share Ownership Trusts which have been formed in sixty one rural districts of the country. To date 61 CSOTs have been formed in Rural District Councils of Zimbabwe with Sixteen of them having received US\$31.3 million seed capital and are now operational, implementing various developmental projects such as roads, schools, hospitals, boreholes, dams and irrigation systems and clinics (Mugabe, 2014).

On 13 November 2012, President Mugabe launched the Mashonaland Central Community Share Ownership Trust and the BCSOT. Freda Rebecca Gold Mine as the qualifying business partner pledged US\$ 10 million as seed capital for the BCSOT with a disbursement of US\$1 million per annum for a period of ten years (Bindura Community Share Ownership Trust Parliamentary Thematic Committee Report, 2014).

The major objective of CSOTs is that the community in the district of a mining operation reaps some benefit from the exploitation of the natural resource in the area they inhabit. The Ministry of Indigenisation and Economic Empowerment indicated that it intended to coordinate the establishment of such Trusts. To this end a Cabinet Steering Committee was established and is chaired by the Minister of Youth Development, Indigenisation and Economic Empowerment. The Steering Committee published an Operational Framework for CSOTs and stipulated that there will be one Trust per District. It has also determined the composition of each Trust. This proposed composition of the Boards of Trustees and signatories to the Trust accounts would ensure that the CSOTs and the finances thereof will be firmly in the hands of individuals aligned to ZANU PF (Matyszak, 2013).

The indigenisation policy encourages establishment of Community Share Ownership Trusts (CSOTs) to manage community shares. This is a noble idea. Andreasson (2008) notes that while necessary, money is not the only factor to consider in rural development. Rural communities also need to be empowered ideologically to deal with the complex rural development matrices. Without a properly coordinated mix of skills, knowledge and attitude, no amount of money will bring about true development in rural communities.

There is however, no law requiring companies to establish CSOTs, let alone one compelling companies to collaborate with the Ministry on the establishment of such trusts or to form them in accordance with the governmental framework. Such law as there is pertaining CSOTs is contained in an amendment51 to the general regulations, section 14B.

Section 14B (2) provides:

A community share ownership scheme or trust that complies with this section maybe taken into consideration when assessing the extent to which a business has achieved or exceeded the minimum indigenisation and empowerment quota.

Such a scheme or trust is referred to in the definition section of the Regulations as a "qualifying scheme or trust". Section 14B (4) makes it clear that it is entirely at the discretion of each business whether to establish a CSOT, providing: 
An owner of a business wishing to use the qualifying scheme or trust for the purpose of this section shall submit to the Minister Form IDG 04 together with a copy of the Deed of Trust of the qualifying scheme or trust.

The proviso to this subsection stipulates that in considering whether a community share ownership scheme or trust should be accepted as a qualifying scheme or trust, the Minister shall have regard to whether the scheme or trust provides that the monies accruing to the scheme or trust will be applied to the benefit of social projects and infrastructure in the community such as schools, hospitals and roads (Matyszak, 2013).

It is therefore implicit from this proviso that the Regulations anticipate that the terms of the CSOT will not be determined by the Ministry. More importantly, in direct contradiction to the government's proclaimed policy and 'Operational Framework for CSOTs' in this regard, the Regulations also provide for the number of Trustees and manner in which the Trustees of each CSOT are to be determined. Section 14B (3) (a) thus provides that, in the case where the

beneficiary community are the residents of a Rural District Council (RDC), the RDC shall have the right to appoint the trustee or trustees; section $14 \mathrm{~B}(3)(\mathrm{b})$ provides that in the case where the beneficiary community are the residents of one or more wards of a RDC, the manner of appointment of the trustee or trustees shall be as agreed between the RDC concerned and the qualifying business; and section 14B (3) (c) provides that in the case where the beneficiary community are the members of a distinct community of persons as defined in a community share ownership scheme, the manner of appointment of the trustees shall be as set out in the Deed of Trust of the community share ownership scheme or trust concerned. Since it is implicit that the company determines the terms of the Trust, which it submits for approval as a qualifying trust, it is implicit that the company will determine the manner of appointment of the Trustee(s) by inserting the same into the Deed of Trust (Matyszak, 2013).

Section 14B(5) stipulates that the funds accruing to the Trusts, established by or in collaboration with an RDC, will be held in a separate account of the RDC and managed by the RDC. Where the Trust is established under subsection 3(c) the management of the funds must be as provided for in the relevant Trust Deed, presumably determined by the company. Accordingly, the government's 'Operational Framework for CSOTs' as to the establishment of Trust Accounts and the management of the funds therein contradicts the Regulations in this regard (Government of Zimbabwe, 2011).

The CSOTS' main objectives are to:

(i) Enable communities to benefit from their God given resources,

(ii) Involve rural communities in the mainstream economy - the national economy,

(iii) Reinforce the role of communities in economic development by enabling them to make decisions on their development priorities,

(iv) Enable rural communities to hold equity in qualifying businesses or companies (Dube, 2013). 


\section{Research Design and Methodology}

The case study was used as a research design. The study followed a qualitative approach. It allowed the researchers to gain insights into participants' views and interactions with the BCSOT. Primary data collection was mainly through key informant interviews and survey questionnaire while documentary search involved sifting through various legislations such the Indigenisation and Economic Empowerment Act and Statutory Instruments.

The sample consisted of 50 respondents from Bindura rural district, 3 key respondents from the BCSOT, 1 from Freda Rebecca Gold Mine and 5 district heads from other relevant ministries. The study used purposive sampling and simple random sampling to select key respondents and other respondents from Bindura rural district. The sample size was a total of 59 respondents.

\section{Research Findings}

The research established that the Indigenisation and Empowerment programme was successful despite some challenges. It was noted that in Mashonaland Central Province only five out of eight Rural District Councils had natural resources from which CSOTs can generate revenue for local communities. Only the BCSOT was operational through Freda Rebecca Gold Mine (FRGM) as the qualifying company in the province. The major challenge has been selective development as other Rural District Councils without CSOTs continue to experience poverty and minimal economic development. Many Zimbabweans in these areas complain of being sidelined (Dube, 2013).

Embedded in the indigenisation policy is the opportunity to strengthen democracy, peace and development in the country. The indigenisation policy involves a transfer of power and wealth from a capitalist system to the previously marginalised people. It presents itself as a source of conflict between the capitalist system and the poor. The success of the policy requires a strong political will among all the stakeholders, namely the state, business, civil society, and the poor people in the country. In most Latin American states, political and economic elites resisted wealth redistribution in favour of the poor; this underpins the persistent weakness of Latin American states (Matunhu, 2012).

The government of Zimbabwe should empower the poor rural communities to ascend out of poverty. The need for government to take the initiative of empowering the poor people in the community is articulated by Nyerere (1967) in Item (i) of the Arusha Declaration which states that it is the responsibility of the state to intervene actively in the economic life of the nation so as to ensure the well-being of all citizens, and so as to prevent the accumulation of wealth to an extent which is inconsistent with the value of equity and equality (Matunhu, 2012)

The current Indigenisation and Economic Empowerment Act 14/2007 in Zimbabwe does not specifically mention the empowerment of disadvantaged communities; rather it talks of empowerment of individuals. Put differently, the Act is more concerned about individual development rather than community development. There is a need for a paradigm shift here; the empowerment policy must address community development issues. 
Indigenisation attempts in Zimbabwe, however, have traces of historically entrenched power imbalances which are rooted in racial supremacy and as such all attempts to rectify this anomaly are often clouded by racial hatred and political emotions. This ultimately overlooks the objective of devising Indigenisation policies. Some quarters of the nation therefore view this policy as a tool to settle racial scores and champion their political supremacy, while others identify the policy as an apt tool to put the destiny of African economies in the indigenous hands through correcting beneficiation skewdness. It is in this regard that the research sought to unravel the underlying political power dynamics that influence the execution or implementation of the Indigenisation Policy in Zimbabwe so as to proffer recommendations and suggestions on coming up with a more appropriate and people-oriented indigenisation framework which transcends selfish political interests (Matunhu, 2012).

\subsection{Composition of the BCSOT Board of Trustees}

The Deed of Trust indicates that the following people should sit on the Board of Trustees:

(i) Chairperson-chief

(ii) Vice chairperson-Bindura Rural District Council (BRDC) Council chairperson

(iii) Secretary- BRDC Chief Executive Officer (CEO)

(iv) Members-Chief, District Administrator (DA), District Youth Development Officer (DYDO), women representative, disabled representative, war veterans representatives, youth representative, lawyer, accountant, qualifying business representative (FRGM) and business representative

The research found out that during the year 2013 and 2014, the BCSOT was funded by FRGM (as qualifying business) through an advance facility pending the finalisation of the pre advanced dividend agreement. Under the arrangement, US\$1 million was pledged for that purpose and out of that amount; US\$ 965,558 was drawn by December 2013 and subsequent US $\$ 157,193$ was drawn in 2014 to pay 2013 creditors as well as financing projects in the new financial year. As at 31 March 2014 a total of US\$1,122,751 was utilised from the facility. Consequently FRGM fulfilled its pledge in the first year of operation of the Trust. Further funding of the second year is still waiting finalisation of the pre-advanced dividend agreement. The research found that the implementation of the Indigenisation and Economic Empowerment Act of 2007 is currently going through various programmes such as the Community Share Ownership Trusts (CSOTs).

The Trust has embarked on forty five projects which were based on needs assessments and the Bindura Rural District Council project bank guided by the Deed of Trust in eighteen wards out of twenty-one benefitting about 107000 out of 125000 people in the district. A needs assessment was carried out by the Board of Trustees from 29 April to 17 April 2013 and 20 to 23 January in 2014. To allow empowerment of the community in line with the Indigenisation and Empowerment Policy, preference was given to more than fifty local suppliers. This also enhanced employment creation for local community with 87 males and 16 females benefiting from projects. 


\section{Macrothink

Table 1: Projects undertaken by BCSOT in BRDC

\begin{tabular}{|l|l|l|}
\hline Project & Amount & Percentage \\
\hline Boreholes & $80,890.82$ & 7.3 \\
\hline Health & $168,831.24$ & 15.23 \\
\hline Education & $287,226.52$ & 25.91 \\
\hline Roads & $96,859.69$ & 8.74 \\
\hline Assets & $376,098.00$ & 33.93 \\
\hline Administration & $98,424.40$ & 9.1 \\
\hline Total & 1108530.00 & 100 \\
\hline
\end{tabular}

Figure 1: Projects undertaken by BCSOT in BRDC

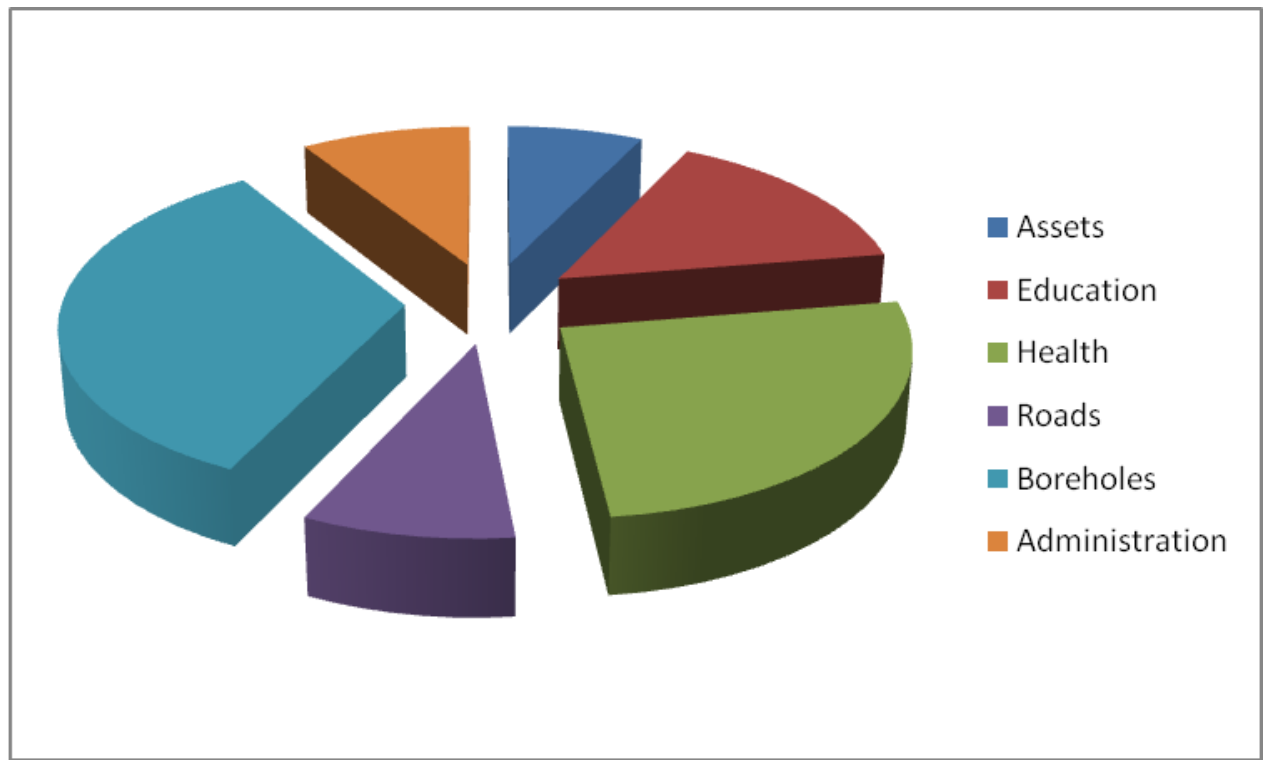

A number of projects and activities were undertaken in different sectors as follows:

All the twenty one wards in the district had benefited from water projects which included drilling and installation of boreholes, supplying of submersible pump sets and water reticulation from borehole to tank. 
$75 \%$ of the respondents agreed that the BCSOT through Bindura Rural District Council had made a significant contribution to their communities in terms of infrastructural development. $25 \%$ of the respondents indicated that instead of the BCSOT should give them money to start income-generating projects and small to medium enterprises so that they would directly benefit from the empowerment initiative. 68\% identified the Indigenisation and Economic Empowerment Act and the statutory instrument for Community Share Ownership Trust (CSOT) as pro-poor policies which can improve the social and economic infrastructure of rural communities.

The CSOTs can be interpreted as part of corporate social responsibility in the mining sector. This is because in terms of section 14 of the Indigenisation and Economic Empowerment (General) Regulations SI 21 of 2010 the revenue realized from the CSOT will be used for community projects such as hospitals, schools, irrigation. Given the fact that the revenue will be used for community project that seeks to uplift the lives of communities, the research argues that the recognition of CSOTs by the law is what may have been lacking in the legal terrain in making it mandatory for mining companies to carry out corporate social responsibility activities. Therefore, it can be persuasively argued that this provision crystallize corporate social responsibility in the law, although the provision does not specifically mention the phrase corporate social responsibility. What it does is simply to recognize some of the key elements of corporate social responsibility. (Zimbabwe Environmental Law Association, 2011).

\section{Conclusion}

Poverty in rural Zimbabwe is as a result of low income from farm livelihood activities, unemployment and underemployment (Chimhowu, Manjengwa and Feresu, 2010). The groups most affected by poverty are women, children, chronically ill persons, and the elderly people. These groups of people have been vulnerable as a result of cultural and traditional systems of Africans which have unconsciously worked in cahoots with the policies of the colonial masters to marginalise economic and social empowerment of these people. National policies and programmes must endeavour to empower the most vulnerable members of the society in order to fight poverty and underdevelopment; indigenisation of foreign-owned companies is an option for dealing with the rural development crisis in the country (Mabhena and Moyo, 2014).

Mate (2002:12) argues that community participation in the management and use of mineral wealth at the local level "could speed up the process of community empowerment and lead to increased pressure on central government for better management of mineral wealth and for greater transparency and accountability in its management". Good governance of natural resources starts with the development of a shared national strategy or vision, with clear and realistic goals, timelines and indicators of achievement. Long term planning is particularly relevant in communities' rich in extractive minerals these extractive industries often span several decades with each stage of the project life cycle-exploration, construction, production, beneficiation, closure-having distinct implications for the host country and community, both in terms of impact environmental, social, and economic and opportunities for spill over 
benefits such as infrastructure expansion and training.

Local communities, local government and the wider public should be engaged prior to, and during development. Efforts to inform and involve the public in decisions about overall vision for a nation's resources must ensure that a diversity of voices is heard. Meaningful involvement enables communities to understand how they will be affected, plan for the pending changes and contribute local knowledge to the design of mitigation and enhancement strategies. Not doing so risks antagonism and possibly conflict. If a decision is made to undertake a resource-based project that will negatively affect some individuals or groups, measures must be taken to ensure that the effect of the change does not lead to deterioration in livelihoods. Ongoing community engagement through community consultative committees or references groups is required of resource developers in some jurisdictions (Mabhena and Moyo, 2014).

Enhancing the capacity of local governments can help to ensure that the benefits of resource-based projects are captured. Good local governance also requires strong communication with other government entities. Mining companies engaging with local RDCs should ensure that the local government represents community perspectives and is congruent to culturally acceptable governance systems. At the same time the country should be cautious in devolving powers to the local level where capacity typically is more limited and opportunities for abuse, corruption and waste maybe evident.

There was widespread agreement by respondents that local communities should be involved in all initiatives of natural resource management in their areas if such initiatives are to succeed. The issue of natural resource management is closely related to the issue of resource ownership. Unfortunately, extractive industries, especially those involved in gold and diamond mining have neglected local communities in pursuit of profits. However, this article argues that the focus must shift to economic empowerment of communities through starting income generating projects, Small to Medium Enterprises (SMEs) and other job creation ventures.

The research has unearthed one of the major fundamental observations that the economic indigenisation process in Zimbabwe is both an economic and political issue, but the political arm seems to dominate and control how the process unfolds and this has regrettably further exposed the previously disadvantaged indigenous populace to continued poverty and suffering. The research argues that the indigenisation and economic empowerment policy was well received because it gives the local communities a sense of ownership and control of their own natural. However, there has been a lot of political interference especially in deciding the projects to be embarked on by the BCSOT. Despite the acceptance that the indigenisation process was long overdue, it is important that more researches be undertaken with regards to the implementation framework. This would assist in the crafting of a more proper and indigenisation and empowerment framework which transcends beyond the current political rhetoric and historical justifications. 


\section{Recommendations}

In light of the above findings and conclusions it would be important to make the following recommendations for the indigenisation and empowerment policy to be effective:

Formulation of a clear legislation - Though the Indigenisation and Economic Empowerment Act guides the broader indigenisation process, there is need for the Ministry of Indigenisation and Economic Empowerment to make the legislation on CSOTs more direct and specific on how it should operate and specific to the needs of local communities. There is also need to ensure clarity and transparency and at the same time promoting investor confidence in the mining sector.

Creation of sense of ownership and an enabling environment - ownership of projects by the local communities and creation of an enabling environment by the CSOTs, RDCs and other local organisations is very important. This would create a collaborative partnership in identifying, planning, allocation of resources for projects to cater for the local needs. The collaborations between different actors would reduce abuse of Trust funds.

Non-political interference- It is very important that there should be no political interference in the composition and management of CSOTs. This will reduce the politicisation of the empowerment process as this has proved to be detrimental to the local communities. In most cases politicians have served personal and party interests at the expense of the benefiting communities.

Use of existing development structures instead of creation of parallel structures- these includes the Village Development Committees (vidcos), Ward Development Committees (wadcos) and the Rural District Development Committees (RDDCs) as enshrined in the Rural District Councils Act (29:33) (1988). The creation of CSOTs has excluded these development structures in the formulation and implementation of local projects. This has created tensions in most RDCs where CSOTs have been formed.

Regulation of CSOTs- This would allow members of the community to choose their own representatives other than the ones prescribed by the state. Most CSOTs have failed to take off because some companies are taking advantage of the legal gaps in the indigenisation laws that give them options in terms of remitting funds to CSOTs and those that have received funds from mining companies are dogged in stories of financial mismanagement.

Incorporation of Corporate Social Responsibility (CSR)- It must be made mandatory in the Minerals Act in order for communities to benefit from the exploitation of resources found in their localities. The CSR programme also helps the company to invest in indigenization and empowerment of the local communities and the government to earn income through royalties and levies which are eventually ploughed back into the rural areas. It also promotes economic diversification and local value addition. 


\section{Macrothink}

Journal of Public Administration and Governance ISSN 2161-7104 2014, Vol. 4, No. 4

\section{References}

Andreasson, S. (2008). 'Indigenisation and Transformation in Southern Africa', Paper prepared for the British International Studies Association Annual Conference, University of Exeter, 15-17th of December 2008.

Bealer, R; Fern, C; Willits, K and Williams, P. (1965). 'Rurality' in American Society: Some Implications of Alternative Definitions. Rural Sociology 30: 255-266.

Bindura Community Share Ownership Trust (2014). Parliamentary Thematic Committee Report. Harare.

Bond, I. (2004) Private Land Contribution to Conservation in South Africa. In Parks in Transition: Biodiversity, Rural Development and the Bottom Line, Child, B. (ed.). Earthscan: London, UK; 29-62.

Chambers, R. (1987). Rural Development: Putting the Last First. Longman Scientific and Technical Publishers, England.

Coombs, W.W and Ahmed. M. (1974). How Non - Formal Education can help. Baltimore and London. The Johns Hopkins University Press.

Development Planning Unit (2001). Implementing the Habitat Agenda: In search of Urban Sustainability. UN-HABITAT; Department for International Development. London.

Dube, C. F. (2013). 'Zimbabwe's Indigenous Programme: The Process, the Benefits and the Challenges.' Institute of Chartered Accountants of Zimbabwe, Winter School, Victoria Falls.

Gaomab, M. (2010). 'The relevance of Black Economic Empowerment (BEE) to the implementation of Competition Policy and Law in Namibia: Is it an Imperative.' www.fesnam.org (Accessed 15 October 2014).

Government of Zimbabwe (2013). Constitution of Zimbabwe Amendment (No. 20) Act of 2013. Government Printer, Harare.

Government of Zimbabwe (2008). Indigenisation and Economic Empowerment Act 14/2007, Government Printers, Harare.

Helmsing, A.H.J. (2010). Perspectives and Practices of Local Economic Development: A Review, ISS, The Hague.

Jones, B and Murphree, M.W. (2001). 'The Evolution of Policy on Community Conservation in Namibia and Zimbabwe'. In African Wildlife and Livelihoods: The Promise and Performance of Community Conservation, Hulme, D and Murphree M. W (eds.). J. Currey: Oxford, UK; 38-58.

Ladele, A. A. (2005). Rural Development Process and Practice. In: Agricultural Extension in Nigeria. (ed.) S. F. Adedoyin. 
Lund, J and Treue, T. (2008). Are We Getting There? Evidence of Decentralized Forest Management from the Tanzanian Miombo Woodlands. World Development 36: 2780-2800

Mabhena, C and Moyo, F. (2014). Community Share Ownership Trust Scheme and Empowerment: The Case of Gwanda Rural District, Matabeleland South Province in Zimbabwe. IOSR Journal of Humanities and Social Sciences 19 (1): 72-85.

Makwiramiti. A. M. (2011): 'In the Name of Economic Empowerment: A Case for South Africa and Zimbabwe'. www.consultancyafrica.com (Accessed 10 October 2014).

Mate, K. 2002. 'Communities, Civil Society Organisations and the Management of Mineral Wealth'. London: International Institute for Environment and Development (IIED) No 16.

Matunhu, J. (2012). The Indigenisation and Economic Empowerment Policy in Zimbabwe: Opportunities and Challenges for Rural Development, Southern Peace Review Journal, 1(2):5-20.

Matyszak, D. (2011). 'Everything You Ever Wanted to Know (and then some) About Zimbabwe's Indigenisation and Economic Empowerment Legislation But (quite rightly) Were Too Afraid to Ask.' www.kubatana.net. Accessed 20 October, 2014.

Matyszak, D. (2013). Digging up the Truth: The Legal and Political Realities of the Zimplats Saga, Research and Advocacy Unit, Harare, Zimbabwe.

Mugabe, R. G. (2014). Speech by His Excellence the President of the Republic of Zimbabwe and Commander-in- Chief of the Zimbabwe Defence Forces on Zimbabwe's $34^{\text {th }}$ Independence Day Celebrations, Harare, Zimbabwe.

Murphree, M. W. (2008). The Strategic Pillars of Communal Natural Research Management: Benefit, Empowerment and Conservation, Pan-African Workshop on Community-based Natural Resource Management Approaches. Niamey, Niger 10th-12th March 2008.

Musarurwa, T. (2012). 'Indigenisation Boom for Workers'. Harare: The Herald, 01 May, 2012.

Mwangi, E. (2007). The Puzzle of Group Ranch Subdivision in Kenya's Maasailand. Development and Change 38: 889-910

Rihoy, E; Chirozva, C and Anstey, S. (2007). 'People are not happy' - Speaking up for Adaptive Natural Resource Governance in Mahenye.' School of Government, University of the Western Cape. South Africa.

Rihoy, E and Maguranyanga, B. (2007). 'Devolution and Democratisation of Natural Resource Management in Southern Africa: A Comparative Analysis of CBNRM Policy Processes in Botswana and Zimbabwe'. Centre for Applied Social Sciences and Programme for Land and Agrarian Studies.

Rono, P.K and Aboud, A.A. (2003). The role of Popular Participation and Community Work Ethic in Rural Development: The Case of Nandi District in Kenya. Journal of Social Development in Africa, 18(2):77-103. 


\section{Macrothink}

Journal of Public Administration and Governance ISSN 2161-7104 2014, Vol. 4, No. 4

Sachedina, H. (2008). 'Wildlife Is Our Oil: Conservation, Livelihoods and NGOs in the Tarangire Ecosystem, Tanzania', Doctoral Thesis, University of Oxford.

Stamm, V. (2000). The Rural Land Plan: An Innovative Approach from Cote d'Ivoire, IIED.

Starkey, M. (2004). 'Commerce and Subsistence: The Hunting, Sale and Consumption of Bush meat in Gabon,' Doctoral Thesis, University of Cambridge.

Sustainable Development Solutions Network (2013). 'Harnessing Natural Resources for Sustainable Development: Challenges and Solutions', Technical Report for the Post 2015 Development Agenda.

Taylor, R and Murphree, M. W. (2007). Case Studies on Successful Southern African NRM Initiatives and their Impact on Poverty and Governance: Masoka and Gairesi Case Studies Zimbabwe, IUCN / USAID FRAME.

Zikhali, D; Ncube, G and Tshuma, N. (2014). From Economic Development to Local Economic Growth: Income Generating Projects in Nkayi District, Zimbabwe. The International Journal of Humanities and Social Sciences 2 (2) 27-33.

Zimbabwe Environmental Law Association (ZELA) (2011). 'Update and Analysis of Extractive Sector and Mining Issues in Zimbabwe.' www.zela.org (accessed 20 October 2014). 